Article

\title{
Effect of PPO-Inhibiting Herbicides on the Growth and Sex Ratio of a Dioecious Weed Species Amaranthus palmeri (Palmer Amaranth)
}

\author{
Mafia M. Rumpa ${ }^{1}$, Ronald F. Krausz ${ }^{2}$, David J. Gibson ${ }^{1, *(1)}$ and Karla L. Gage ${ }^{3}$ \\ 1 Department of Plant Biology, Southern Illinois University Carbondale, Carbondale, IL 62901-6509, USA; \\ kbdrumpa@gmail.com \\ 2 Belleville Research Center, Southern Illinois University Carbondale, Belleville, IL 62221, USA; \\ rkrausz@siu.edu \\ 3 Department of Plant, Soil, and Agricultural Systems, Southern Illinois University Carbondale, Carbondale, \\ IL 62901-4416, USA; kgage@siu.edu \\ * Correspondence: djgibson@siu.edu; Tel.: +1-618-453-3231
}

Received: 1 May 2019; Accepted: 28 May 2019; Published: 30 May 2019

check for updates

\begin{abstract}
Amaranthus palmeri S. Watson (Palmer amaranth) is a fast-growing, dioecious, highly competitive agricultural weed species, which is spreading across the US Midwest. Population sex ratios are an important consideration in the management of $A$. palmeri populations as this species has become resistant to several herbicide sites of action, and there is need to minimize seed production by female plants. Environmental conditions, particularly stressors, may influence sex ratios, and herbicides act as major stressors and evolutionary filters in agricultural fields. Amaranthus spp. have shown a tendency for rapid evolution of herbicide resistance, with the frequency of protoporphyrinogen oxidase (PPO)-inhibitor resistance increasing across the Midwestern US. A greenhouse experiment was conducted to investigate the effect of two PPO-inhibiting herbicide treatments of either lactofen or fomesafen on four different Illinois populations (Cahokia, Collinsville, Rend Lake, and Massac). Plants raised from seed from the Massac population were tallest, and both males and females from this population also had the highest vegetative biomass. Female plants from the Collinsville population had more reproductive biomass than male plants. Control populations were male-biased (Cahokia, Collinsville), female-biased (Masaac), and 1:1 (Rend Lake). Lactofen shifted the male-biased populations to female-biased or 1:1 and the female-biased population to 1:1. Fomesafen-treated populations were male-biased or 1:1. This study suggests that PPO-inhibiting herbicide treatments may influence the growth and sex ratio of A. palmeri populations, which is an underlying factor in the rate of herbicide evolution in this species. An understanding of the underlying mechanisms of how external factors influence sex ratios may eventually provide an opportunity to reduce seed production in populations by shifting sex ratios towards a male bias.
\end{abstract}

Keywords: Amaranthus palmeri; Palmer amaranth; AMAPA; dioecy; PPO-inhibiting herbicides; protoporphyrinogen oxidase; lactofen; 2-ethoxy-1-methyl-2-oxoethyl 5-[2-chloro-4-(tri-fluoromethyl) phenoxy]-2-nitrobenzoate; fomesafen; 5-[2-chloro-4-(trifluoromethyl)phenoxy]-N-(methylsulfonyl)-2nitrobenzamide; weed control

\section{Introduction}

In some flowering species, dioecy is a sexually dimorphic phenomenon [1]. In these species, male-to-female sex ratios are expected to be 1:1 because of parental investment due to the effect of deleterious incidence, and reliance on selection to maintain unbiased sex ratios [2]. Thus, the sex ratio of dioecious species should generally be close to unity when the male and female reproduction costs 
are equal. The origin of departures from this ratio remains a long-standing problem in biology related to ecology and evolutionary systems determined by complex ecological (biotic, abiotic factors that influence living organisms), demographic (socioeconomic characteristics of a population) and genetic factors [3]. Some of these biotic and abiotic factors, including physical and chemical characteristics of the environment that are reported to shift sex expression in plant populations, include day length, light intensity, atmospheric chemistry, mineral nutrients, soil moisture, and ambient temperature [4].

Sexual expression of an individual may be strongly correlated with environmental stress. A number of previous studies reported that sexual expression of a species may be altered through environmental factors, such as in the case of Amaranthus rudis (Moq.) J. D. Sauer populations where application of composted swine manure produced more males in the population than females [5]. Higher nitrogen content in the soil can change the sex expression towards more males for Zea mays L. [6]. On the other hand, higher nitrogen rates (200 vs. $80 \mathrm{~kg} \mathrm{ha}^{-1} \mathrm{~N}$ ) [7], ultraviolet light and irradiation with gamma rays [8], and exposure to carbon monoxide [9] can produce a more female-biased population for Cannabis sativa L. Sexual expression can also be altered through the application of plant hormones, such as in the case of Spinacea oleracea L. populations where the application of gibberellins and kinetin produced more female-biased populations grown under long days. On the other hand, AMO 1618 (a plant growth retardant) and abscisic acid application under long day photoperiods produced more male-biased populations [10,11]. Environmental conditions may be responsible for sex expression of some species, such as Amaranthus tuberculatus (Moq.) Sauer (syn. Amaranthus rudis Sauer, A. latissimus Riddell) which produced female-biased populations in Illinois, whereas Ontario populations yielded the expected 1:1 male-to-female sex ratios [12,13].

In the case of dioecious flowering plants, a biased sex ratio may result if sex-biased mortality happens subsequently after maternal investment or if dissimilarities occur with the cost of reproduction of each sex $[14,15]$. Due to limited availability of resources allocated to reproduction, plant populations may experience a fitness cost for reproduction. Females need more resources than males and, therefore, generally express a higher fitness cost than males for reproductive allocation. The rate of recurrence of higher male reproduction is more likely related to the lower reproductive allocation in male plants [16]. With environmental stress or when there are limited resources, higher female reproductive costs can lead to vulnerability to stress, and result in male-biased populations in dioecious species [17]. These differences in resource allocation result in dissimilarities in the rate of recurrence of flowering, which causes sex-biased mortality. Generally, dioecious plant populations exhibit male- or female-biased sex ratios if the cost of production or reproductive fitness between male and female populations are not equal over time, and these altered or biased sex ratios can impact population growth rates over time [17].

Amaranthus palmeri S. Watson (Palmer amaranth; AMAPA) is a dioecious, obligate outcrossing, agricultural weed in the Amaranthaceae family native to the southern and southwestern part of the USA in California, Texas, and New Mexico. Under ideal conditions and without competition, this species can produce $200,000-600,000$ seeds per female plant [18-20]. Its high photosynthetic rates, aggressive growth pattern, abundant seed production, prolonged periods of germination, and capability to adapt to a wide range of environmental conditions make it a competitive and successful weed in cropping systems of the US. Depending on its density and the crop growth stage, the presence of A. palmeri results in severe yield losses reported up to $94 \%$ by competing with the crop plants for water, light, and nutrients [21-28]. Along with competitive interference, A. palmeri can also affect seedling growth of crops such as grain sorghum, carrot, cabbage, onion, and tomato through allelopathic effects [29,30].

The mechanisms governing dioecy in A. palmeri are largely unknown, i.e., sex-determining chromosomes are not reported [31]. A recent study examined potential gender-specific DNA sequences of the closely related species, A. tuberculatus, and found that gender-related tags (64-base-pair sequences) were heavily male-biased, suggesting that males are the heterogametic sex; only one-fifth of females had gender-specific tags, suggesting that a non-functional male locus may be present in some female 
plants [32]. Better knowledge of dioecy in A. palmeri and the factors that could influence the sex ratio would have significant implications for managing herbicide-resistant biotypes of this species.

Few studies have related herbicides to sex ratios in plant populations. In the case of Cirsium arvense (L.) Scop. (Canada thistle), males had greater vegetative regrowth following applications of glyphosate, and these differences in vegetative reproduction might change the sex ratios in the field [33]. A greenhouse study of $A$. palmeri indicated no departure from a 1:1 ratio of males to females in glyphosate-resistant and glyphosate-susceptible populations [34]. However, a field study in 2015 and 2016 [35] showed that post-emergence (or foliar) application of the protoporphyrinogen oxidase (PPO)-inhibiting herbicide lactofen and pre-emergence (or soil) application of PPO-inhibiting herbicides saflufenacil, flumioxazin, and the combination of fluthiacet-methyl + pyroxasulfone (PPO-inhibiting + long chain fatty acid (LCFA)-inhibiting herbicide) altered the sex ratio of A. palmeri populations leading to a female bias. Additionally, pre-emergence applications of pendimethalin (a mitosis inhibitor) and non-treated controls expressed a female bias, while all other treatments did not deviate from a 1:1 male to female ratio [35]. Protoporphyrinogen oxidase (PPO)-inhibiting herbicides have the potential to manage glyphosate- and acetolacatate synthase (ALS)-inhibitor-resistant weed populations and have become foundational to effective weed control for many of the broadleaf weed species in large-scale agricultural crop production systems, but these herbicides have now begun to fail due to the evolution of resistance in A. tuberculatus and A. palmeri populations to soil and foliar applied PPO-inhibiting herbicides [36-41].

In order to investigate the role of PPO-inhibiting herbicides in manipulating sex ratios in A. palmeri populations, greenhouse research was conducted to investigate the male-to-female sex ratio of four different populations of $A$. palmeri after exposure to two post-emergence PPO-inhibiting herbicides, lactofen (2-ethoxy-1-methyl-2-oxoethyl 5-[2-chloro-4-(tri-fluoromethyl) phenoxy]-2-nitrobenzoate) and fomesafen (5-[2-chloro-4-(trifluoromethyl)phenoxy]-N-(methylsulfonyl)-2-nitrobenzamide). Hypotheses tested were: 1) Application of PPO-inhibiting herbicides affects the male-to-female sex ratio, and (2) PPO-inhibiting herbicides differentially affect the growth characteristics of male and female plants.

\section{Materials and Methods}

The greenhouse experiment was conducted at the Horticultural Research Centre and the Tree Improvement Center of Southern Illinois University Carbondale (SIUC) and was initiated in March 2016. The experiment was arranged in a completely randomized block design with three replicates and the experimental unit was a group of 10 pots each containing a single plant. The experiment investigated sex ratios among four different $A$. palmeri seed sources treated with post-emergence applications of PPO-inhibiting herbicides.

PPO-inhibiting herbicide applications included two different PPO-inhibiting herbicides, fomesafen (Flexstar ${ }^{\circledR}$, Syngenta Crop Protection, Research Triangle Park, NC, USA) and lactofen (Cobra ${ }^{\circledR}$, Valent USA Corporation, Walnut Creek, CA, USA), which are commonly used herbicides for Amaranthus spp. control in local soybean production. A prior field study [35] included two post-emergence PPO-inhibiting herbicides, i.e., lactofen and fomesafen and 13 pre-emergence applications, which included three PPO-inhibiting herbicides at various use rates, three LCFA-inhibiting herbicides, one mixture of PPO- + LCFA-inhibiting herbicides, one mitosis-inhibiting herbicide, and one untreated control. The post-emergence PPO-inhibiting herbicide, lactofen, led to a departure from the expected 1:1 sex ratio, with female-biased populations and, therefore, was chosen for investigation in this experiment. The post-emergence application of the PPO-inhibiting herbicide, fomesafen, did not lead to a departure of the expected 1:1 sex ratio, and was included in the greenhouse study as a comparison. The field trial confirmed that $A$. palmeri was sensitive to both of these PPO-inhibiting herbicides in 2015, and resistance to PPO-inhibiting herbicides was not suspected in any of the populations used in this study; however, in 2016, the Collinsville population was documented as $18.8 \%$ heterozygous for the glycine 210 deletion which confers PPO-inhibitor-resistance to fomesafen and lactofen, indicating the early stages of resistance development $[42,43]$. 
Amaranthus palmeri seeds were collected from four fields in Illinois, i.e., glyphosate-resistant A. palmeri seeds from Cahokia (latitude 38.563276, longitude -90.131007) and Collinsville (latitude 38.688847, longitude -90.016194) and glyphosate-susceptible seeds from Rend Lake (latitude 38.131023, longitude -88.915100) and Massac (latitude 37.509131, longitude -88.593149). Seed from the Cahokia and Collinsville populations were collected during 2014 and 2015, respectively. Seed from the Rend Lake and Massac populations were collected during 2013 and 2010, respectively. After collection, all seeds were preserved by refrigeration at $2.2^{\circ} \mathrm{C}$.

Seeds were germinated on a flat and grown in greenhouse growing media containing $70 \%-80 \%$ Canadian sphagnum peat moss, perlite, vermiculite, dolomite lime $\mathrm{pH}$ adjuster, and a wetting agent (Professional Growing Mix, SunGro ${ }^{\circledR}$ Horticulture Sunshine, Santa Rosa, CA, USA). After germination, the seedlings were allowed to reach the 1st and 3rd true leaf stage and then were transplanted into $10.2 \mathrm{~cm}$ pots (one seedling per pot). Pots were placed on two benches in the greenhouse at the SIUC Horticultural Research Center (HRC); and then three weeks after herbicide application, they were transferred to a greenhouse at the SIUC Tree Improvement Center (TIC) on three benches (experimental blocks), which act as replicates in the experiment. Plants were maintained in a $16 \mathrm{~h}$ photoperiod with $430 \mathrm{~W}$ sodium lighting providing $250 \mu \mathrm{mol} \mathrm{m} \mathrm{s}^{-1}$ of supplemental photosynthetically-active radiation. The air temperature was maintained near $32( \pm 5)^{\circ} \mathrm{C}$ during the course of the experiment in both greenhouses. The temperature of both greenhouses was recorded with a data logger. Once plants reached $10-12 \mathrm{~cm}$ in height with 8-12 true leaves, herbicide applications were made in a spray chamber using an XR 8002 nozzle applying 15 GPM at 30 psi with lactofen and fomesafen at $158 \mathrm{~g}$ ai ha ${ }^{-1}$ and $165 \mathrm{~g}_{\text {ai ha }}{ }^{-1}$, respectively. The herbicide rate and application timing methodology was established in an unpublished pilot study in which rates were decreased and weed size was increased, compared to labeled rates for control, in order to achieve approximately 30\% survival of treated plants. Typical application rates for lactofen and fomesafen are 219 and $420 \mathrm{~g}$ ai ha ${ }^{-1}$; the established dose in the pilot study represented 28 and $58 \%$ reductions, respectively. Additionally, application target sizes for A. palmeri are less than six leaves for both active ingredients and less than $7.6 \mathrm{~cm}$ in height for lactofen $[44,45]$.

After the application of herbicides, plants were returned from the spray chamber to greenhouse benches. Plants were visually rated for herbicide injury at 7,14 , and 28 days after treatment (DAT). For each treatment, 10 plants were selected on the basis of herbicide injury. Severely injured plants were selected for monitoring and assessment of their sex determination and growth characteristics. The most severely injured plants (95\%-99\% injury) were selected based on injury ratings for additional measures. Three replications of 360 plants were monitored including untreated plants. Growth characteristics were assessed by monitoring leaf number and height of the plant at application, the height of the plant at 2, 4, and 6 weeks $(14,28$, and 42 DAT) after herbicide application, and the date of 1st flowering. Additionally, the biomass of reproductive parts was measured. Upon flowering, when anthers and the stigma were prominently visible, plants were examined to determine sex. Once the sex of a plant was confirmed, the above-ground biomass was collected by cutting the plant from the soil surface and weighing the whole plant after oven drying at $48.9 \mathrm{C}$ for three days. The reproductive parts were separated by collecting inflorescences and clipping all the flowers from the stem and weighing them after oven drying.

\section{Statistical Analysis}

A three-way repeated measures mixed-model ANOVA was performed to identify the effects of four different $A$. palmeri populations, sex, and herbicide treatment on height over time. Biomass of reproductive and vegetative parts and flowering date were analyzed with three-way ANOVA. Separate paired t-tests on the proportion of males-to-females in each replicate group of ten pots were performed testing deviation from a 1:1 sex ratio; all analyses were conducted in SAS 9.4 (SAS Institute, Cary, NC, USA). 


\section{Results}

\subsection{Effect of Population Sources and Herbicide Treatments on Height}

Three-way Repeated Mixed Model Analysis indicated that there were significant interactions between population sources and $\operatorname{sex}\left(F_{3,955}=5.49, p<0.001\right)$ (Figure 1a), between population sources and herbicide treatments $\left(F_{6,949}=8.23, p<0.0001\right)$ (Figure $\left.1 b\right)$, herbicide treatments over time $\left(F_{4,871}=25.11\right.$, $p<0.0001$ ) (Figure 2$)$, and population sources over time $\left(F_{6,871}=5.01, p<0.0001\right)$ (Figure 3) on A. palmeri plant height (Table 1). Male and female plants from the Massac populations were significantly taller than plants grown from all other population sources. There was no difference in height between male and female plants from either the Massac or Cahokia population. Female plants from the Collinsville population were taller than the male plants from this population, whereas male plants from Rend Lake were taller than females from this population (Figure 1).

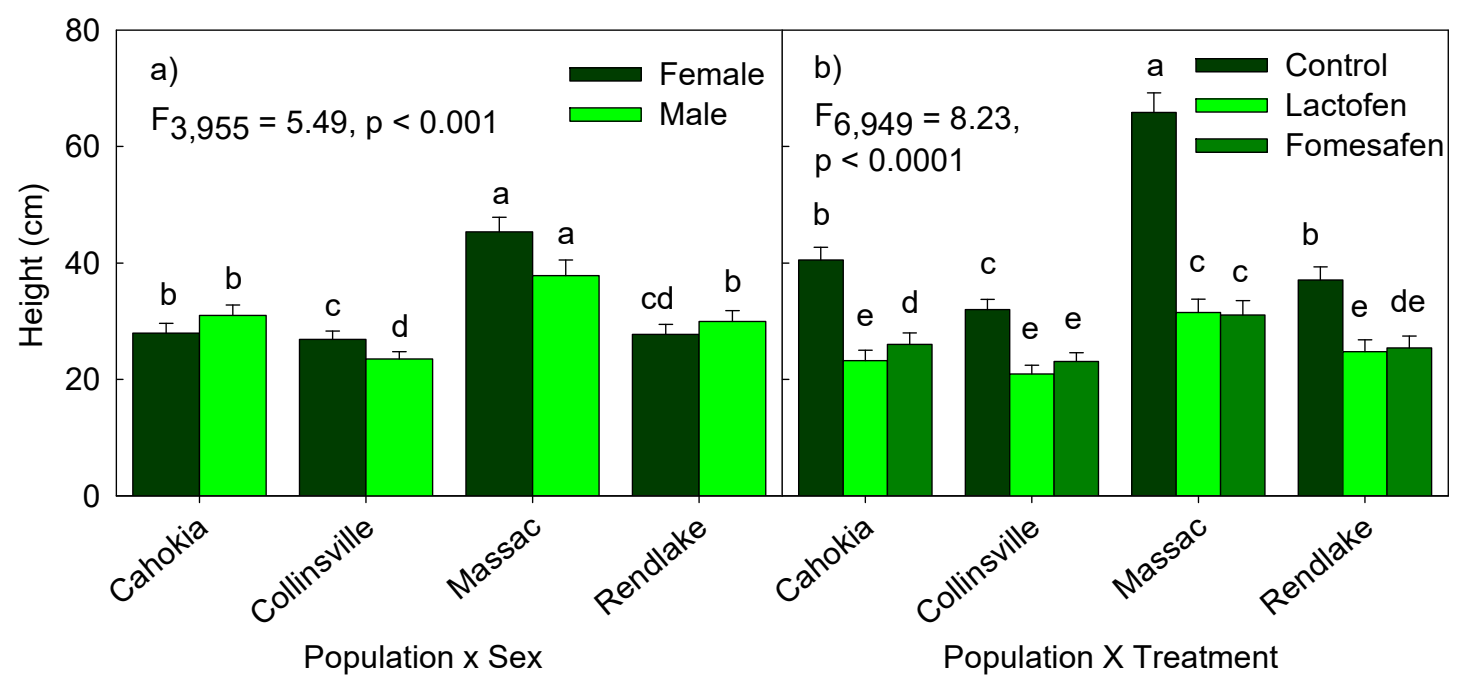

Figure 1. Height $(\mathrm{cm} \pm \mathrm{se}$ ) of Amaranthus palmeri plants from four population sources (Cahokia, Collinsville, Massac, and Rend Lake) (a) by sex (female and male), and (b) by PPO-inhibiting herbicide treatment. Bars with different letters are significantly different $(p \leq 0.05)$.

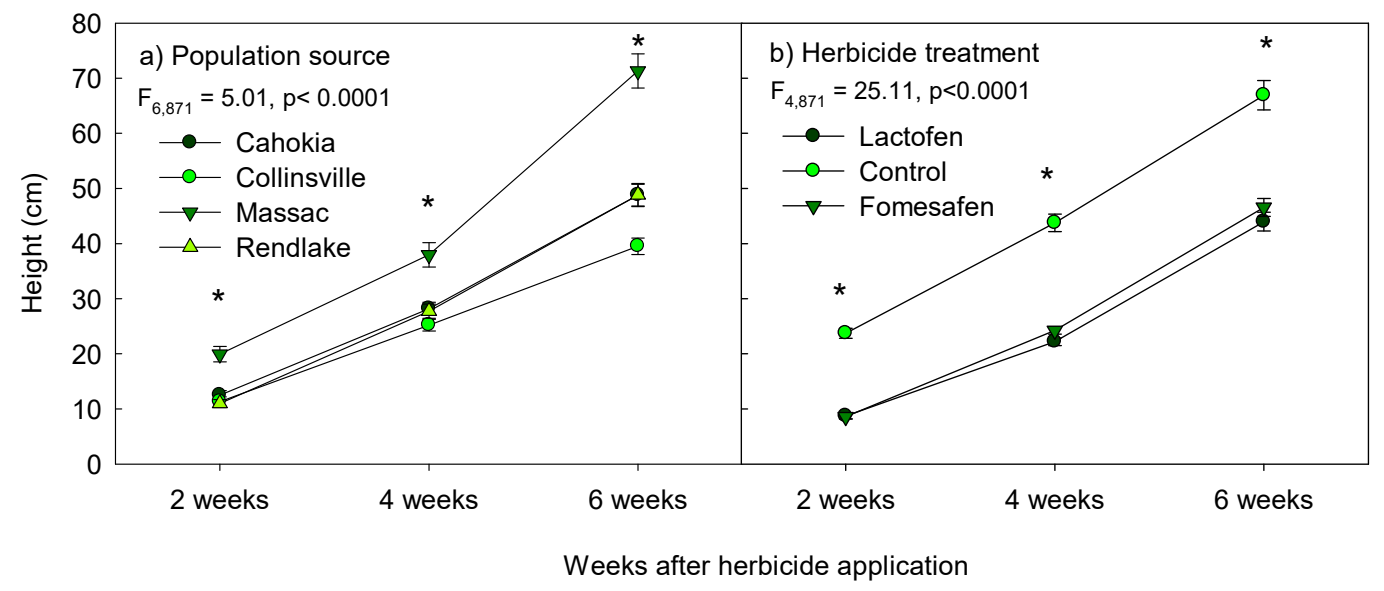

Figure 2. Effect of (a) population source (Cahokia, Collinsville, Massac, and Rend Lake) and (b) PPO-inhibiting herbicides (lactofen and fomesafen) on height $(\mathrm{cm} \pm \mathrm{se})$ at 2, 4, and 6 weeks after herbicide application. Asterisk $\left.{ }^{*}\right)$ represents significantly different values $(p \leq 0.05)$. 

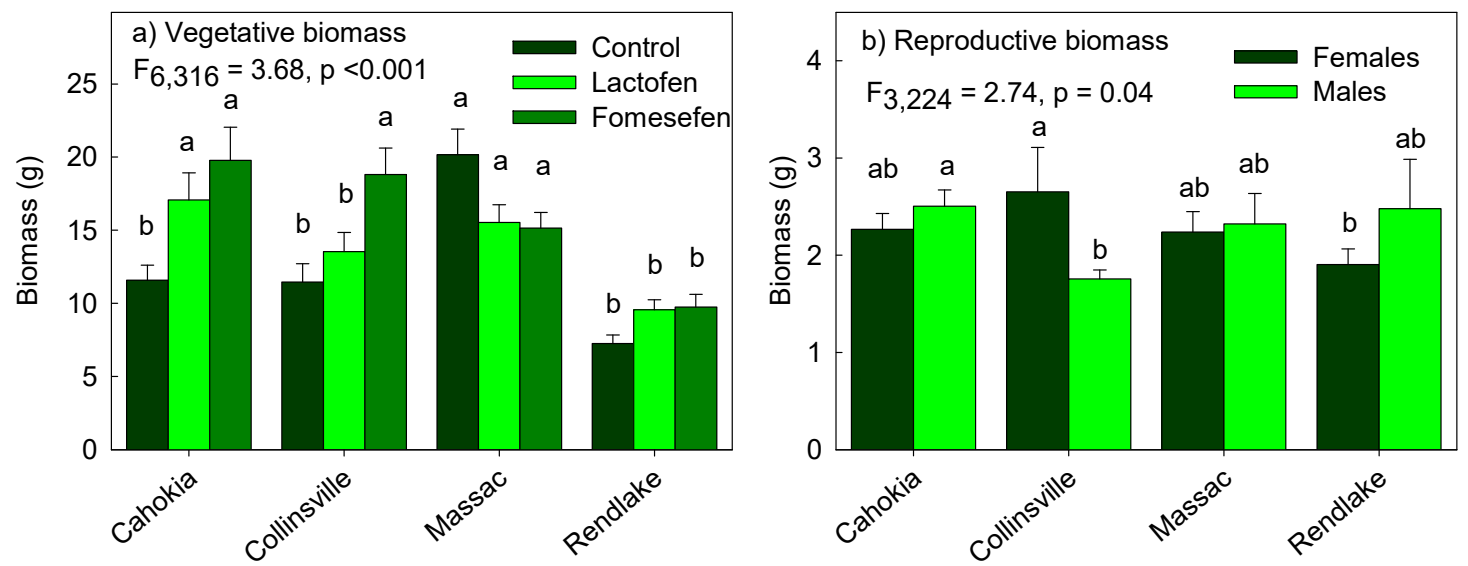

Population Source

Figure 3. Biomass (mean $\pm \mathrm{se}$ ) at flowering stage of Amaranthus palmeri plants from four population sources (Cahokia, Collinsville, Massac and Rend Lake) (a) vegetative biomass by treatment following application of PPO-inhibiting herbicides (lactofen and fomesafen), and (b) by sex. Bars with different letters are significantly different from each other $(p \leq 0.05)$.

Table 1. Results (F and $p$ values) from 3-way ANOVA repeated mixed model analysis of four A. palmeri population sources (pop), herbicide treatments (treat), time (time) and sex on plant height (cm). Significant values $(p \leq 0.05)$ are highlighted in bold.

\begin{tabular}{ccc}
\hline Effect & F Value & Pr $>$ F \\
\hline pop & $\mathbf{7 6 . 0 5} 5_{3,960}$ & $<\mathbf{0 . 0 0 0 1}$ \\
treat & $\mathbf{8 3 . 5 8 _ { 2 , 5 4 . 4 }}$ & $<\mathbf{0 . 0 0 0 1}$ \\
pop $\times$ treat & $\mathbf{8 . 2 3 _ { 6 , 9 4 9 }}$ & $<\mathbf{0 . 0 0 0 1}$ \\
sex & $<0.10_{1,902}$ & 0.95 \\
pop $\times$ sex & $\mathbf{5 . 4 9 _ { 3 , 9 5 5 }}$ & $\mathbf{0 . 0 0 1}$ \\
treat $\times$ sex & $0.29_{2,875}$ & 0.75 \\
pop $\times$ treat $\times$ sex & $1.72_{6,945}$ & 0.11 \\
time & $\mathbf{1 3 8 6 . 5 7}_{2,871}$ & $<\mathbf{0 . 0 0 0 1}$ \\
pop $\times$ time & $\mathbf{5 . 0 1} 6,871$ & $<0.0001$ \\
treat $\times$ time & $\mathbf{2 5 . 1 1 _ { 4 , 8 7 1 }}$ & $<\mathbf{0 . 0 0 0 1}$ \\
pop $\times$ treat $\times$ time & $1.26_{12,871}$ & 0.24 \\
sex $\times$ time & $0.44_{2,871}$ & 0.65 \\
pop $\times$ sex $\times$ time & $0.27_{6,871}$ & 0.95 \\
treat $\times$ sex $\times$ time & $0.01_{4,871}$ & 0.99 \\
pop $\times$ treat $\times$ sex $\times$ time & $0.65_{12,871}$ & 0.80 \\
\hline
\end{tabular}

Untreated control plants from each of the four population sources were taller than the populations treated with both herbicides (Figure 1b). There were no differences in height in response to lactofen or fomesafen herbicide in plants from the Collinsville, Massac, and Rend Lake populations. Cahokia plants treated with lactofen were shorter than plants from this population treated with fomesafen (Figure 1b). Plant height increased over time for all the population sources 2, 4, and 6 weeks after herbicide application. Plants from the Massac populations were the tallest plants throughout, and plants from Collinsville populations were the shortest by six weeks. The height of plants from Cahokia and Rend Lake populations were intermediate in height between the Massac and Collinsville plants by six weeks (Figure 2a). Herbicide treatments led to significant differences in height through time. All the untreated control populations were taller than the populations treated with lactofen and fomesafen herbicides. The height of lactofen- and fomesafen-treated populations increased through time but did not differ from each other (Figure 2b). 


\subsection{Effect of Population Sources and Herbicide Treatments on Vegetative Biomass}

There was a significant effect of population sources and herbicide treatments on vegetative biomass at flowering stage $\left(F_{6,316}=3.68, p<0.0015\right)$ (Table 2$)$. The mean value for vegetative biomass showed that the untreated control plants from the Massac populations had greater vegetative biomass than the untreated controls of other populations. Rend Lake treated plants had the lowest vegetative biomass compared with treated plants from other populations. There was no significant difference between Cahokia plants treated with lactofen and fomesafen in terms of vegetative biomass. Collinsville plants treated with fomesafen had greater vegetative biomass than plants treated with lactofen or untreated control plants (Figure 3a). Female plants had a larger vegetative biomass than male plants regardless of population source or herbicide treatment (female plants mean biomass $=16.1 \pm 0.6 \mathrm{~g}$, male plants $=$ $12.0 \pm 0.6 \mathrm{~g})$.

Table 2. Results (F and $p$ values) from the three-way ANOVA of four A. palmeri population sources (P), herbicide treatments $(\mathrm{T})$, and sex $(\mathrm{S})$ for plant biomass measures (vegetative and reproductive).

\begin{tabular}{ccccccc}
\hline & $\begin{array}{c}\text { Vegetative } \\
\text { Biomass }\end{array}$ & & $\begin{array}{c}\text { Reproductive } \\
\text { Biomass }\end{array}$ & & \multicolumn{2}{c}{$\begin{array}{c}\text { Flowering } \\
\text { Date }\end{array}$} \\
\hline Effect & F value & Pr $>$ F & F value & Pr $>$ F & F value & Pr $>$ F \\
\hline $\mathrm{P}$ & $29.38_{3,1}$ & 0.12 & $0.50_{3,222}$ & 0.68 & $36.28_{3,326}$ & $<0.0001$ \\
$\mathrm{~T}$ & $0.54_{2,31.6}$ & 0.009 & $0.38_{2,18.5}$ & 0.69 & $115.20_{2,49.9}$ & $<0.0001$ \\
$\mathrm{P} \times \mathrm{T}$ & $3.68_{6,316}$ & 0.0015 & $1.84_{6,215}$ & 0.09 & $0.10_{6,324}$ & 0.99 \\
$\mathrm{~S}$ & Infty & $<.0001$ & $0.29_{1,267}$ & 0.59 & $26.89_{1,333}$ & $<0.0001$ \\
$\mathrm{P} \times \mathrm{S}$ & $0.56_{3,330}$ & 0.64 & $2.74_{3,224}$ & 0.04 & $1.54_{3,333}$ & 0.21 \\
$\mathrm{~T} \times \mathrm{S}$ & $0.18_{2,333}$ & 0.31 & $0.03_{2,255}$ & 0.97 & $3.02_{2,333}$ & 0.05 \\
$\mathrm{P} \times \mathrm{T} \times \mathrm{S}$ & $0.66_{6,330}$ & 0.68 & $0.96_{6,220}$ & 0.45 & $0.70_{6,333}$ & 0.69 \\
\hline
\end{tabular}

\subsection{Effect of Population Sources and Herbicide Treatments on Reproductive Biomass}

There was a significant interaction between sex and population sources but not herbicide treatments on reproductive biomass at the flowering stage $\left(F_{3,224}=2.74, p<0.04\right)$ (Table 2$)$. The mean value for reproductive biomass showed that only male and female plants from the Collinsville population were significantly different from each other for reproductive biomass (females with higher reproductive biomass than males). However, there was no significant difference in reproductive biomass between males and females from Cahokia, Massac, and Rend Lake populations (Figure 3b).

\subsection{Effect of Population Sources and Herbicide Treatments on the Flowering Date}

There was a significant interaction between sex and herbicide treatments, but not population sources on flowering dates $\left(F_{2,333}=3.02, p<0.05\right)$ (Table 2$)$. The mean value for the flowering date showed that flowering date was significantly different between male and female plants. All the untreated control populations produced earlier flower induction and were significantly different from all other populations. There were no significant differences within lactofen- and fomesafen-treated male populations, as well as no significant differences within lactofen- and fomesafen-treated female populations for the flowering date (Figure 4).

\subsection{Effect of Population Sources and Herbicide Treatments on the Male-to-female Sex Ratios}

Paired t-tests on the proportions of males to females (testing deviations from 1:1 sex ratio, i.e., 0.5 proportions for males and females) indicated that within the context of our greenhouse experiment, the herbicides altered the sex ratio of some populations compared with 1:1 expected untreated controls. Cahokia untreated controls, Cahokia populations treated with lactofen, all the treated and untreated Collinsville populations, Massac untreated controls, and Massac populations treated with fomesafen herbicide gave a significant departure from a 1:1 male-to-female sex ratio. Four out of seven treatments had male-biased sex ratios, i.e., Cahokia untreated control, Collinsville untreated control, Collinsville 
population treated with fomesafen, and Massac population treated with fomesafen. Populations from Collinsville were more strongly male-biased when treated with fomesafen compared with male-biased untreated control populations. Cahokia populations treated with fomesafen, Massac populations treated with lactofen, and all the treated Rend Lake populations regardless of treatment (herbicides or controls) were not significantly different from a 1:1 male-to-female sex ratio (Figure 5, Table 3).

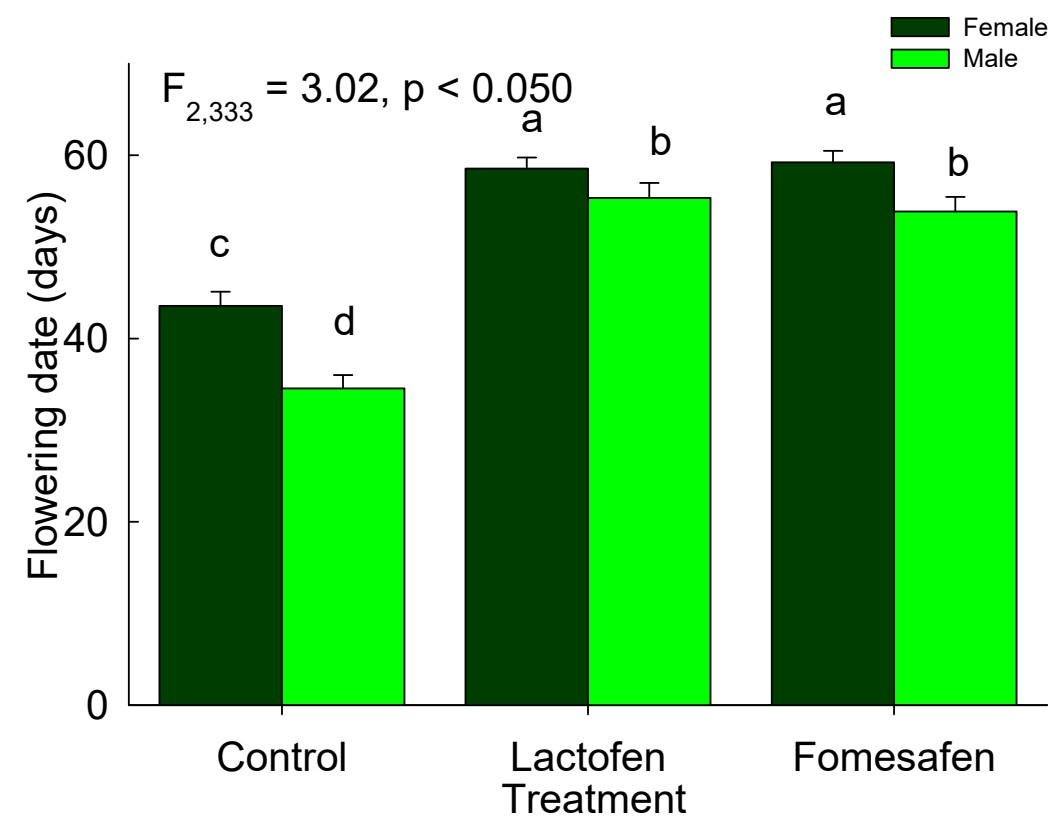

Figure 4. Effect of PPO-inhibiting herbicides (lactofen and fomesafen) by sex on flowering date (days). Bars with different letters are significantly different from each other $(p \leq 0.05)$.

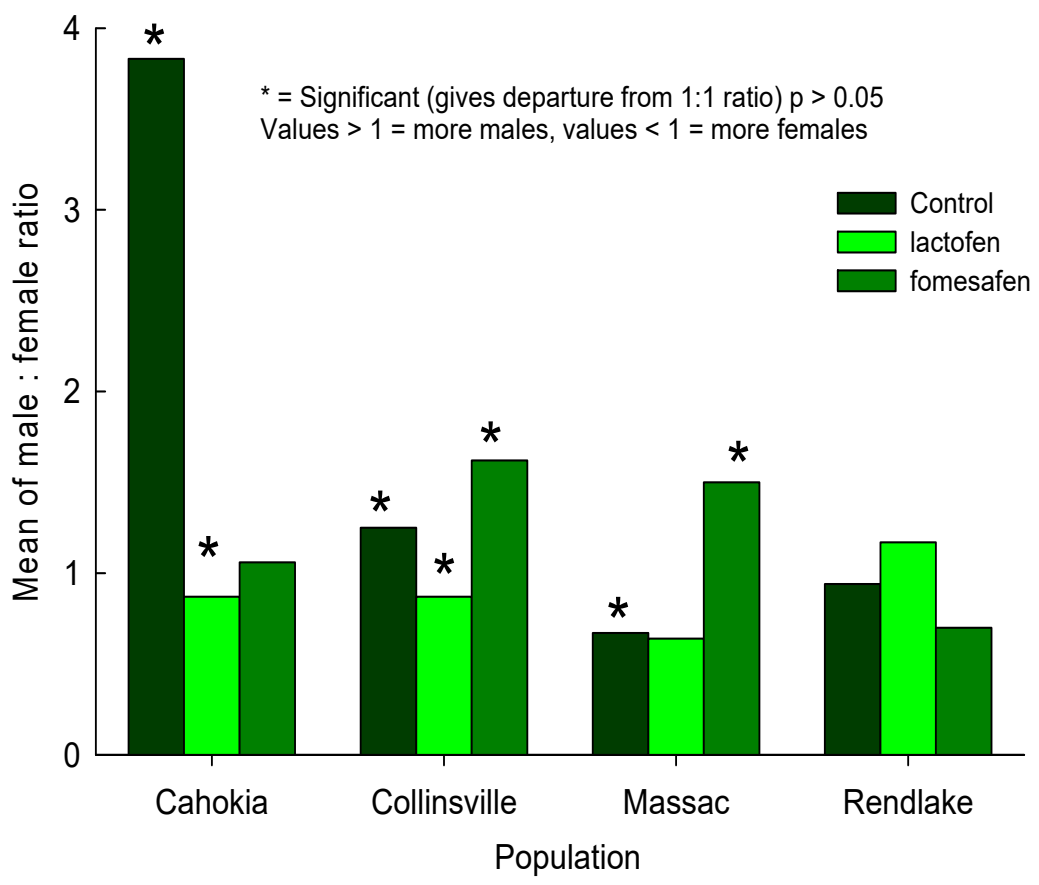

Figure 5. The male-to-female sex ratio of Amaranthus palmeri plants from four population sources (Cahokia, Collinsville, Massac, and Rend Lake) by treatment following application of PPO-inhibiting herbicides (lactofen and fomesafen). Asterisk ${ }^{*}$ ) represents significant deviation from 1:1 male-to-female sex ratio. 
Table 3. Results from paired t-tests, testing the deviation from a 1:1 sex ratio of four A. palmeri populations following the effects of two PPO-inhibiting herbicide treatments (lactofen and fomesafen). Values $(p \leq 0.05)$ highlighted in bold give no departure from 1:1 male-to-female sex ratio. Degrees of freedom for $t$-values $=2$.

\begin{tabular}{cccc}
\hline Treatment & Population & $\boldsymbol{t}$-Value & $\boldsymbol{p}$-Value \\
\hline lactofen & Cahokia & -3.59 & 0.070 \\
lactofen & Collinsville & -3.59 & 0.070 \\
lactofen & Massac & -4.35 & $\mathbf{0 . 0 4 9}$ \\
lactofen & Rendlake & -6.50 & $\mathbf{0 . 0 2 3}$ \\
control & Cahokia & -0.69 & 0.560 \\
control & Collinsville & -2.17 & 0.163 \\
control & Massac & -2.50 & 0.130 \\
control & Rendlake & -4.25 & $\mathbf{0 . 0 5 0}$ \\
fomesafen & Cahokia & -4.33 & $\mathbf{0 . 0 4 9}$ \\
fomesafen & Collinsville & -1.70 & 0.231 \\
fomesafen & Massac & -2.80 & 0.173 \\
fomesafen & Rendlake & -6.06 & $\mathbf{0 . 0 2 6}$ \\
\hline
\end{tabular}

\section{Discussion}

In this study, height, vegetative, and reproductive biomass, flowering date, and male-to-female sex ratios of four $A$. palmeri populations in response to two PPO-inhibiting herbicides lactofen and fomesafen were examined. The invasive potential of $A$. palmeri populations was assessed based on these parameters, considering height, biomass, and flowering date of A. palmeri as measures of this species competitive effect on agricultural crops. Male-to-female sex ratio appears to be a key factor to emphasize in the management of this invasive species in agricultural fields. The differences in growth in response to herbicides among the four populations is consistent with the known occurrence of A. palmeri ecotypes [46] which may be in response to glyphosate resistance or cropping systems [47].

Specifically, the four A. palmeri populations exhibited gender-related variations in height in response to the PPO-inhibiting herbicides fomesafen and lactofen. In the case of short-lived dioecious species, such as annual weeds, females are often taller than males, although this variation may depend on life history stage [48]. In the present study, one population was consistently taller than the other three. Plants from the Massac population were consistently larger when treated with herbicides and might exhibit size-asymmetric competition for resource uptake and resource utilization [49]. Plant height is considered to be an important factor in considering competition with neighboring species, including crops, as taller plants can capture more resources than shorter plants [50]. Crops growing under the shade of neighboring plants will receive reduced light intensity and altered light quality that can inhibit growth and development indicating approaching competition during canopy development [51]. On the other hand, tall male plants are beneficial for wind-pollinated species to maximize propagule dispersion by the wind [52]. Hence, plants from the Rend Lake population, where males were taller than females, and plants from the Massac population, which were taller regardless of gender, may have a greater impact on long-distance pollen dispersal and a greater contribution to cross-pollination among populations than plants from the shorter growing populations.

Biomass is an indicator of competitiveness [53]. Untreated control plants from the Massac populations had greater vegetative biomass than other populations. Therefore, plants from the Massac populations may have greater competitive ability than other populations. On the other hand, Collinsville plants treated with fomesafen had greater vegetative biomass than untreated control plants and plants treated with lactofen. The differential response of plants from this population to the two herbicides may be because they needed to accumulate sufficient biomass to support reproduction following herbicide application.

In the case of dioecious species, size dimorphism is a natural phenomenon that is due to the sexually different allocation patterns for both sexes. Comparatively, vegetative growth may be similar 
for both male and female plants prior to flowering stage [54], when the reproductive stages begin, females may grow larger than males and live longer. This difference in size and longevity between males and females provides evidence for sexual dimorphism [55]. Only males and females from the Collinsville population differed in reproductive biomass with females producing more reproductive biomass than the males. Females may be investing more resources in the production of larger leaves for photosynthesis, and supplying more carbon to fruits for better and higher seed set. Environmental heterogeneity could also affect sexual differences and reproductive allocation [56].

There are sex-specific differences in growth and reproduction, which are consistent with life history traits that affect the longevity of male and female populations. In dioecious species, there is a senescence strategy for males, which tend to exhibit narrower phenological windows compared to females [48]. In this study we observed that all the untreated control male plants, as well as lactofen, and fomesafen-treated male plants produced flowers (and, thus, could be sexed) earlier than the females produced flowers. Male plants invested more resources for root growth which may be due to the high early investment of nitrogen rich pollen, leading to decreased photosynthetic rates. These processes restrict the above-ground vegetative growth for males, although it is challenging to determine the proper resource currencies to evaluate reproductive expenditure in dioecious species [57]. Male-biased sex ratios could be associated with the higher reproductive allocation of females as well as a consequence of earlier and more frequent onset and flowering of males. Variation in environmental factors can also influence the flowering patterns of males and females in dioecious species [58]. Amaranthus palmeri is a $\mathrm{C}_{4}$ species and light is a limiting factor for growth and reproduction of this species [59]. This study was conducted under greenhouse conditions with controlled temperature and photoperiod, which could account for early male flowering, as flowering intensity depends on the day length [60].

Dioecious plant populations commonly exhibit deviations from the expected 1:1 primary sex ratio after parental investment [61-63]. As A. palmeri is developing resistance mechanisms to herbicides, effective tools to manage this invasive species in agricultural fields need to be developed. Manipulation of sex ratios via herbicides could be an effective way to manage A. palmeri if relative densities of seed-producing female plants can be reduced. Therefore, sex-ratio-specific management practices implemented by the growers have the potential to become an integrated tactic in managing herbicide-resistant $A$. palmeri populations. Both herbicides applied in the present study resulted in different effects on these A. palmeri populations. Lactofen and fomesafen are both PPO-inhibiting herbicides but the induced sex ratio expression was not same for both herbicides on all the populations. Populations treated with lactofen were female-biased or 1:1, and populations treated with fomesafen were male-biased or 1:1. The differential effect of fomesafen may be due to the presence of the adjuvant system in the Flexstar ${ }^{\circledR}$ herbicide, which increases herbicide absorption and translocation. A priority for early season control of $A$. palmeri could also be beneficial as late emerging populations have been observed to be more male-biased than early season populations [64]. Populations with a female-biased sex ratio may need more effective management practices than populations having more male-biased sex ratios where fewer seeds will be produced.

The greenhouse-controlled conditions of this experiment produced male-biased populations. As PPO-inhibiting herbicides have the ability to destroy the enzymatic pathway by damaging cell constituents it is possible that differences in sex expression could be related to imbalances of hormonal systems. Previous studies have shown that the sex expression of some dioecious species (Mercurialis spp., Vitis spp., Spinacia spp., Cannabis spp.) was related to hormonal pathway systems [65-68]. Cytokinin, a growth hormone, produces more females in normal growth conditions and produces more males in stressful conditions. Male sterility of Mercurialis annua L. is controlled by sterile S cytoplasm when $S$ cytoplasm interacts with nuclear genes $I, R 1$, and $R 2$. The feminizing hormone cytokinin alters the sex of the male sterile mutant to female [69]. It is possible that for A. palmeri following stressful conditions placed upon the plants by the herbicides, plants could not produce enough cytokinins, and produced more male-biased populations. On the other hand, environmental factors, such as photoperiod, day length, soil moisture, and soil fertility, are also responsible for affecting and shifting 
the sex ratio of a variety of species $[4,70,71]$. Further study is needed to investigate whether any of these or other factors determine sex ratio expression in $A$. palmeri. There is an urgent need to reduce seed immigration of A. palmeri across its range [72]. This research suggests that sex ratios in A. palmeri populations may deviate from 1:1 in response to stressors, such as herbicide application. In the future, it may be possible to manage $A$. palmeri populations by shifting the sex ratio towards male dominance and hence reduce seed production.

Author Contributions: Conceptualization: R.F.K., K.L.G., D.J.G.; methodology: K.L.G., D.J.G.; formal analysis: M.M.R., K.L.G., D.J.G.; investigation: M.M.R.; resources: K.L.G.; data curation: D.J.G.; writing—original draft preparation: D.J.G.; writing—review and editing: M.M.R., K.L.G., R.F.K., D.J.G.; supervision: K.L.G., D.J.G.; project administration: K.L.G.; funding acquisition: K.L.G. All authors discussed the contents of the manuscript and approved the submission.

Funding: This research received no external funding.

Acknowledgments: We thank Joe Matthews and Eric Miller for their help at various stages of the research and Pat Tranel for his comments on the findings presented here.

Conflicts of Interest: The authors declare no conflict of interest.

\section{References}

1. Nicotra, A. Sex ratio variation and spatial distribution of Siparuna grandiflora, a tropical dioecious shrub. Oecologia 1998, 115, 102-113. [CrossRef]

2. Fisher, R.A.S. The Genetical Theory of Natural Selection; Dover: New York, NY, USA, 1958.

3. Charlesworth, D. Plant sex chromosomes. Ann. Rev. Plant Biol. 2016, 67, 397-420. [CrossRef]

4. Freeman, D.; Harper, K.; Charnov, E. Sex change in plants: Old and new observations and new hypotheses. Oecologia 1980, 47, 222-232. [CrossRef]

5. Liebman, M.; Menalled, F.D.; Buhler, D.D.; Richard, T.L.; Sundberg, D.N.; Cambardella, C.A.; Kohler, K.A. Impacts of composted swine manure on weed and corn nutrient uptake, growth, and seed production. Weed Sci. 2004, 52, 365-375. [CrossRef]

6. Heslop-Harrison, J. The experimental modification of sex expression in flowering plants. Biol. Rev. 1957, 32, 38-90. [CrossRef]

7. Van der Werf, H.M.; Van Geel, W.; Van Gils, L.; Haverkort, A. Nitrogen fertilization and row width affect self-thinning and productivity of fibre hemp (Cannabis sativa L.). Field Crops Res. 1995, 42, 27-37. [CrossRef]

8. Nigam, R.K.; Varkey, M.; Reuben, D.E. Irradiation induced changes in flower formation in Cannabis sativa L. Biol. Plant. 1981, 23, 389-391. [CrossRef]

9. Heslop-Harrison, J.; Heslop-Harrison, Y. Studies on flowering-plant growth and organogenesis. II. The modification of sex expression in Cannabis sativa by carbon monoxide. Proc. R. Soc. Edinb. Biol. 1957, 66, 424-434.

10. Culafic, L.; Neskovic, M. Effect of growth substances on flowering and sex expression in isolated apical buds of Spinacia oleracea. Physiol. Plant. 1980, 48, 588-591. [CrossRef]

11. Culafic, L.; Konjevic, R.; Neskovic, M. Flowering of in vitro grown spinach shoots in the presence of the herbicide Sandoz 9789. Biol. Plant. 1983, 25, 155-157. [CrossRef]

12. Lemen, C. Allocation of reproductive effort to the male and female strategies in wind-pollinated plants. Oecologia 1980, 45, 156-159. [CrossRef]

13. Costea, M.; Weaver, S.E.; Tardif, F.J. The biology of invasive alien plants in Canada. 3. Amaranthus tuberculatus (Moq.) Sauer var. rudis (Sauer) Costea \& Tardif. Can. J. Plant Sci. 2005, 85, 507-522. [CrossRef]

14. Lloyd, D.G.; Webb, C. Secondary sex characters in plants. Bot. Rev. 1977, 43, 177-216. [CrossRef]

15. Delph, L.F.; Meagher, T.R. Sexual dimorphism masks life history trade-offs in the dioecious plant Silene latifolia. Ecology 1995, 76, 775-785. [CrossRef]

16. Bierzychudek, P.; Eckhart, V. Spatial segregation of the sexes of dioecious plants. Am. Nat. 1988, 132, 34-43. [CrossRef]

17. Dawson, T.E.; Ehleringer, J.R. Gender-specific physiology, carbon isotope discrimination, and habitat distribution in boxelder, Acer negundo. Ecology 1993, 74, 798-815. [CrossRef] 
18. Sauer, J.D. The grain Amaranthus: A survey of their history and classification. Ann. Mo. Bot. Gard. 1950, 37, 561-632. [CrossRef]

19. Steckel, L.E. The dioecious Amaranthus spp.: Here to stay. Weed Technol. 2007, 21, 567-570. [CrossRef]

20. Keeley, P.E.; Carter, C.H.; Thullen, R.J. Influence of planting date on growth of Palmer amaranth (Amaranthus palmeri). Weed Sci. 1987, 35, 199-204. [CrossRef]

21. Massinga, R.A.; Currie, R.S.; Trooien, T.P. Water use and light interception under Palmer amaranth (Amaranthus palmeri) and corn competition. Weed Sci. 2003, 51, 523-531. [CrossRef]

22. Moore, J.W.; Murray, D.S.; Westerman, R.B. Palmer Amaranth (Amaranthus palmeri) effects on the harvest and yield of grain sorghum (Sorghum bicolor). Weed Technol. 2004, 18, 23-29. [CrossRef]

23. Klingaman, T.E.; Oliver, L.R. Palmer amaranth (Amaranthus palmeri) interference in soybeans (Glycine max). Weed Sci. 1994, 42, 523-527. [CrossRef]

24. Bensch, C.N.; Horak, M.J.; Peterson, D. Interference of redroot pigweed (Amaranthus retroflexus), Palmer amaranth (A. palmeri), and common waterhemp (A. rudis) in soybean. Weed Sci. 2003, 51, 37-43. [CrossRef]

25. Morgan, G.D.; Baumann, P.A.; Chandler, J.M. Competitive impact of Palmer Amaranth (Amaranthus palmeri) on cotton (Gossypium hirsutum) development and yield. Weed Technol. 2001, 15, 408-412. [CrossRef]

26. Burke, I.C.; Schroeder, M.; Thomas, W.E.; Wilcut, J.W. Palmer amaranth interference and seed production in peanut. Weed Technol. 2007, 21,367-371. [CrossRef]

27. Meyers, S.L.; Jennings, K.M.; Schultheis, J.R.; Monks, D.W. Evaluation of flumioxazin and s-metolachlor rate and timing for Palmer amaranth (Amaranthus palmeri) control in sweetpotato. Weed Technol. 2010, 24, 495-503. [CrossRef]

28. Meyers, S.L.; Jennings, K.M.; Monks, D.W. Herbicide-based weed management programs for Palmer amaranth (Amaranthus palmeri) in sweetpotato. Weed Technol. 2013, 27, 331-340. [CrossRef]

29. Menges, R.M. Weed seed population dynamics during six years of weed management systems in crop rotations on irrigated soil. Weed Sci. 1987, 35, 328-332. [CrossRef]

30. Connick, W.; Bradow, J.; Legendre, M.; Vail, S.; Menges, R. Identification of volatile allelochemicals from Amaranthus palmeri S. Wats. J. Chem. Ecol. 1987, 13, 463-472. [CrossRef]

31. Ward, S.M.; Webster, T.M.; Steckel, L.E. Palmer Amaranth (Amaranthus palmeri): A review. Weed Technol. 2013, 27, 12-27. [CrossRef]

32. Sadeque, A.; Brown, P.J.; Tranel, P.J. Towards a novel control strategy for dioecious Amaranthus: Identification of gender-specific DNA sequences. In Proceedings of the Weed Science Society of America, Tuscon, AZ, USA, 6-9 February 2017.

33. Thomas, J.T.; Michael, E.E.; Peter, T.K. Effect of moisture stress and glyphosate on adventitious shoot growth of Canada Thistle (Cirsium arvense). Weed Sci. 1998, 46, 59-64.

34. Giacomini, D.; Westra, P.; Ward, S.M. Impact of genetic background in fitness cost studies: An example from glyphosate-resistant Palmer amaranth. Weed Sci. 2014, 62, 29-37. [CrossRef]

35. Rumpa, M.M. Effect of PPO-Inhibiting Herbicides on Growth Characteristics and Sex Ratio of a Dioecious Weed Species Amaranthus palmeri (Palmer Amaranth). Master's Thesis, Southern Illinois University, Carbondale, IL, USA, 2017.

36. Dan Hess, F. Light-dependent herbicides: An overview. Weed Sci. 2000, 48, 160-170. [CrossRef]

37. Wuerffel, R.J.; Young, J.M.; Matthews, J.L.; Young, B.G. Characterization of PPO-inhibitor-resistant waterhemp (Amaranthus tuberculatus) response to soil-applied PPO-inhibiting herbicides. Weed Sci. 2015, 63, 511-521. [CrossRef]

38. Lee, R.M.; Hager, A.G.; Tranel, P.J. Prevalence of a novel resistance mechanism to PPO-inhibiting herbicides in waterhemp (Amaranthus tuberculatus). Weed Sci. 2008, 56, 371-375. [CrossRef]

39. Lermontova, I.; Grimm, B. Overexpression of plastidic protoporphyrinogen IX oxidase leads to resistance to the diphenyl-ether herbicide acifluorfen. Plant Physiol. 2000, 122, 75-84. [CrossRef]

40. Schwartz-Lazaro, L.M.; Norsworthy, J.K.; Scott, R.C.; Barber, L.T. Resistance of two Arkansas Palmer amaranth populations to multiple herbicide sites of action. Crop Prot. 2017, 96, 158-163. [CrossRef]

41. Salas-Perez, R.A.; Burgos, N.R.; Rangani, G.; Singh, S.; Paulo Refatti, J.; Piveta, L.; Tranel, P.J.; Mauromoustakos, A.; Scott, R.C. Frequency of Gly-210 Deletion Mutation among Protoporphyrinogen Oxidase Inhibitor-Resistant Palmer Amaranth (Amaranthus palmeri) Populations. Weed Sci. 2017, 65, 718-731. [CrossRef] 
42. Heap, I. The International Survey of Herbicide Resistant Weeds. 2019. Available online: http://www. weedscience.org/in.asp (accessed on 20 May 2019).

43. Jenkins, M.E.; Krausz, R.F.; Matthews, J.L.; Gage, K.L.; Walters, S.A. Control of volunteer Horseradish and Palmer Amaranth (Amaranthus palmeri) with Dicamba and Glyphosate. Weed Technol. 2017, 31, 852-862. [CrossRef]

44. Anonymous. Cobra Herbicide Product Label; EPA Reg. No. 59639-34. Valent USA Corporation: Walnut Creek, CA, USA. Available online: https://s3-us-west-1.amazonaws.com/www.agrian.com/pdfs/Cobrar_Herbicide_ Label1y.pdf (accessed on 20 May 2019).

45. Anonymous. Flexstar Herbicide Product Label; EPA Reg. No. 100-1101. Syngenta Crop Protection, LLC: Greensboro, NC, USA. Available online: https://s3-us-west-1.amazonaws.com/www.agrian.com/pdfs/ Flexstar1g_Label.pdf (accessed on 20 May 2019).

46. Bond, J.A.; Oliver, L.R. Comparative growth of Palmer amaranth (Amaranthus palmeri) accessions. Weed Sci. 2006, 54, 121-126. [CrossRef]

47. Bravo, W.; Leon, R.G.; Ferrell, J.A.; Mulvaney, M.J.; Wood, C.W. Differentiation of life-history traits among Palmer Amaranth populations (Amaranthus palmeri) and Its relation to cropping systems and glyphosate sensitivity. Weed Sci. 2017, 65, 339-349. [CrossRef]

48. Obeso, J.R. The costs of reproduction in plants. New Phytol. 2002, 155, 321-348. [CrossRef]

49. Schwinning, S.; Weiner, J. Mechanisms determining the degree of size asymmetry in competition among plants. Oecologia 1998, 113, 447-455. [CrossRef]

50. Nagashima, H.; Hikosaka, K. Plants in a crowded stand regulate their height growth so as to maintain similar heights to neighbours even when they have potential advantages in height growth. Ann. Bot. 2011, 108, 207-214. [CrossRef]

51. Schwartz, L.M.; Gibson, D.J.; Young, B.G. Do plant traits predict the competitive abilities of closely related species? AoB Plants 2016, 8, plv147. [CrossRef]

52. Barrett, S.C.; Yakimowski, S.B.; Field, D.L.; Pickup, M. Ecological genetics of sex ratios in plant populations. Philos. Trans. R. Soc. Lond. B. Biol. Sci. 2010, 365, 2549-2557. [CrossRef]

53. Gough, L.; Grace, J.B.; Taylor, K.L. The Relationship between species richness and community biomass: The importance of environmental variables. Oikos 1994, 70, 271-279. [CrossRef]

54. Putwain, P.; Harper, J.L. Studies in the dynamics of plant populations: V. Mechanisms governing the sex ratio in Rumex acetosa and R. acetosella. J. Ecol. 1972, 60, 113-129. [CrossRef]

55. Zluvova, J.; Zak, J.; Janousek, B.; Vyskot, B. Dioecious Silene latifolia plants show sexual dimorphism in the vegetative stage. BMC Plant Biol. 2010, 10, 1471-2229. [CrossRef]

56. Delph, L.F.; Herlihy, C.R. Sexual, fecundity, and viability selection on flower size and number in a sexually dimorphic plant. Evol. Int. J. Org. Evol. 2012, 66, 1154-1166. [CrossRef]

57. Delph, L.F.; Lu, Y.; Jayne, L.D. Patterns of resource allocation in a dioecious Carex (Cyperaceae). Am. J. Bot. 1993, 80, 607-615. [CrossRef]

58. Antos, J.A.; Allen, G.A. Patterns of reproductive effort in male and female shrubs of Oemleria cerasiformis: A 6-year study. J. Ecol. 1999, 87, 77-84. [CrossRef]

59. MacRae, A.; Webster, T.; Sosnoskie, L.; Culpepper, A.; Kichler, J. Cotton yield loss potential in response to length of Palmer amaranth (Amaranthus palmeri) interference. J. Cotton Sci. 2013, 17, 227-232.

60. Bonduriansky, R.; Maklakov, A.; Zajitschek, F.; Brooks, R. Sexual selection, sexual conflict and the evolution of ageing and life span. Funct. Ecol. 2008, 22, 443-453. [CrossRef]

61. Field, D.L.; Pickup, M.; Barrett, S.C.H. Ecological context and metapopulation dynamics affect sex-ratio variation among dioecious plant populations. Ann. Bot. 2013, 111, 917-923. [CrossRef]

62. Field, D.L.; Pickup, M.; Barrett, S.C.H. Comparative analysis of sex-ratio variation in dioecious flowering plants. Evol. Int. J. Org. Evol. 2013, 66, 661-672. [CrossRef]

63. Gibson, D.J.; Menges, E.S. Population structure and spatial pattern in the dioecious shrub Ceratiola ericoides. J. Veg. Sci. 1994, 5, 337-346. [CrossRef]

64. Spaunhorst, D.J.; Devkota, P.; Johnson, W.G.; Smeda, R.J.; Meyer, C.J.; Norsworthy, J.K. Phenology of five Palmer amaranth (Amaranthus palmeri) populations grown in northern Indiana and Arkansas. Weed Sci. 2018, 66, 457-469. [CrossRef]

65. Chailakhyan, M.K.; Khryanin, V.N. Effect of growth regulators and role of roots in sex expression in spinach. Planta 1978, 142, 207-210. [CrossRef] 
66. Louis, J.P.; Augur, C.; Teller, G. Cytokinins and differentiation processes in Mercurialis annua: Genetic regulation, relations with auxins, indoleacetic acid oxidases, and sexual expression patterns. Plant Physiol. 1990, 94, 1535-1541. [CrossRef]

67. Negi, S.; Olmo, H. Induction of sex conversion in male Vitis. J. Grape Vine Res. 1971, 10, 1-19. [CrossRef]

68. Fechter, I.; Hausmann, L.; Daum, M.; Sörensen, T.R.; Viehöver, P.; Weisshaar, B.; Töpfer, R. Candidate genes within a $143 \mathrm{~kb}$ region of the flower sex locus in Vitis. Mol. Gen. Genet. 2012, 287, 247-259. [CrossRef] [PubMed]

69. Louis, J.P.; Durand, B. Studies with the dioecious angiosperm Mercurialis annua L. $(2 n=16)$ : Correlation between genic and cytoplasmic male sterility, sex segregation and feminizing hormones (cytokinins). Mol. Gen. Genet. 1978, 165, 309-322. [CrossRef]

70. Janoušek, B.; Široký, J.; Vyskot, B. Epigenetic control of sexual phenotype in a dioecious plant, Melandrium album. Mol. Gen. Genet. 1996, 250, 483-490. [CrossRef] [PubMed]

71. Martin, A.; Troadec, C.; Boualem, A.; Rajab, M.; Fernandez, R.; Morin, H.; Pitrat, M.; Dogimont, C.; Bendahmane, A. A transposon-induced epigenetic change leads to sex determination in melon. Nature 2009, 461, 1135-1138. [CrossRef]

72. Davis, A.S.; Schutte, B.J.; Hager, A.G.; Young, B.G. Palmer amaranth (Amaranthus palmeri) damage niche in Illinois soybean is seed limited. Weed Sci. 2015, 63, 658-668. [CrossRef]

(C) 2019 by the authors. Licensee MDPI, Basel, Switzerland. This article is an open access article distributed under the terms and conditions of the Creative Commons Attribution (CC BY) license (http://creativecommons.org/licenses/by/4.0/). 